Lucrările Seminarului Geografic Dimitrie Cantemir

Vol. 45, October 2017, pp. 63-80

http://dx.doi.org/10.15551/lsgdc.v45i0.06

\title{
Historical development of municipal solid waste land- based storage and disposal policies, programs and practices in the US: 1933-1997
}

\section{Hüseyin Özgür1}

${ }^{1}$ Pamukkale University, Faculty of Economics and Administrative Sciences, Denizli, Turkey.

To cite this article: Özgür, H. (2017). Historical development of municipal solid waste landbased storage and disposal policies, programs and practices in the US: 1933-1997. Lucrările Seminarului Geografic Dimitrie Cantemir, Vol. 45, pp. 63-80. DOI: 10.15551/lsgdc.v45i0.06

To link to this article: http://dx.doi.org/10.15551/lsgdc.v45i0.06 


\title{
HISTORICAL DEVELOPMENT OF MUNICIPAL SOLID WASTE LAND- BASED STORAGE AND DISPOSAL POLICIES, PROGRAMS AND PRACTICES IN THE US: 1933-1997
}

\author{
Hüseyin Özgür ${ }^{1}$
}

\begin{abstract}
The practice of ocean dumping of municipal solid wastes was banned in 1933 in the US. Thousands of landfills have been closed due to state and federal regulations and substandard conditions. These closings have resulted in building larger regional and/or privatized landfills in the US and pressures to find new sites or expand existing ones. Federal policymakers responded with new and stricter legislation to the severity of the solid waste issues. The most significant regulation was the Resource Conservation and Recovery Act of 1976 (RCRA) and its amendments. Both closure of landfills and public opposition to landfilling create pressures to heavily utilize alternative waste disposal methods: incineration, composting, recycling, and source reduction. This study is a historical analysis of American states' land-based municipal solid waste storage and disposal policies, programs and practices under the influence of related federal regulations from the period of 1933 to 1997. It is questioned in an historical manner why and to what extent do states use and restrict land-based municipal solid waste disposal methods and how it changed during most of the $20^{\text {th }}$ Century?
\end{abstract}

Keywords: Municipal solid waste disposal, historical analysis, American states, open dumping, sanitary landfilling

\section{Introduction}

For a long time, the United States has viewed as a country with much land which in fact it is an important natural resource to be protected. Contamination of land, negative externalities of land use and possible future land scarcities, at least in densely populated areas, loss of prime agricultural land, and other issues, after mid-1960s, are seen as important policy issues. The lack of landfill capacity and skyrocketing municipal and industrial solid waste disposal costs of the late 1980s and early 1990s in the USA is believed over during the late 1990s (Darcey 1992; Goldstein and Glenn 1997; Repa and Blakey 1996). It seems that new concerns are added to the U.S. landfilling in particular and solid waste disposal crisis in general; these crises had started as environmental (El-Fadel, Findikakis, Leckie 1997), and health / sanitation concerns (Goddard 1995); however regional capacity (Darcey 1992), resource conservation, cost, intergenerational justice crisis and concerns have been added gradually. Lodge and Rayport $(1991,128)$ stated that "the U.S. is running short of landfill capacity and local communities, states, and regions face mounting and critical environmental choices." Regionally, some parts of the country like the Northeast, New York-New Jersey,

\footnotetext{
${ }^{1}$ Pamukkale University, Faculty of Economics and Administrative Sciences, Department of Political Science and Public Administration, Pamukkale, 20070, Denizli, Turkey, hozgur@pau.edu.tr
} 
Florida, and Hawaii suffer from chronic landfill crisis (Goldstein and Glenn 1997; Repa and Blakey 1996). Environmental and health impacts of solid waste landfills and open or wild dumping before 1970s also are/were of great importance (Denison and Ruston 1990).

It seems that when issue is limited to municipal solid waste disposal, there is enough suitable land nationwide in the USA for solid waste storage through sanitary landfills. With the addition of the disposal of other wastes (industrial, mining, and agricultural solid wastes, hazardous wastes, sewage and sludge) land-based waste disposal and its adverse impact on land, water, and air reached critical negative levels since early 1960s, especially during 1980s and early 1990s (Özgür 1998, 8). Municipal solid waste was a small portion (200 million tons) within the annual 8 billion tons of solid waste stream in the United States during early 1990s. The ratio of municipal solid wastes to total waste stream remain almost constant during decades. Disposal of municipal and construction solid wastes get major attention because of its high visibility to laypersons through curbside collection, and landfills.

In 1960 an estimated $30 \%$ of municipal solid waste generated in the United States was combusted in old-fashioned incinerators without energy recovery. When pollution controls began to be required, the old incinerators that did not meet the new standards were phased out (Kreith 1994, 3.28-3.29). In the 1960s and the early 1970s, a large percentage of MSW were burned, means were subject to wild dumping and uncontrolled disposal. The remainder was dumped and often it was burned at the dump to reduce its volume.

Reese $(1983,288)$ stated that waste disposal and its land use problems are major pollution concerns. The Office of Technology Assessment (1992) repeatedly emphasizes the difficulty of siting new landfills and the need to conserve landfill space. With the fear of water pollution from landfills, many residents are concerned about old and new landfills. States respond with bold programs to land-based solid waste disposal issues. Hird (1994) emphasized that more sites were added to the Superfund national priority list every year than are sites cleaned up. Nearly $20 \%$ of the Superfund national priority list sites are old landfills. The longterm costs and environmental issues raised by land-based solid waste disposal can be high in future. Lawrence and Khurana (1997) studied public policy concerns and financial reporting issues related to municipal landfills for which Superfund settlements have occurred; and, they concluded that environmental liabilities do represent a serious threat to the financial health of some municipalities.

Historically, through the mid-1980s, incineration declined considerably and landfills became difficult to site, waste generation continued to increase and the burden on the landfill capacity of landfills in the US grew dramatically. As a percent of total generation, landfilling has consistently decreased from $83.2 \%$ of generation in 1986 to $56.9 \%$ in 1995 (USEPA 1996, 113-114). "Stimulation provided by state waste reduction legislation in recent years has been causing the landfilling rate to decline and increased use of alternatives such as recycling and composting" (Kreith 1994, 5.2).

The number of landfills in the United States declined from 20,000 in 1978 to nearly 3,000 in 1996 (Goldstein and Glenn 1997). Shortage of landfill capacity is very acute in some parts of the country, especially the Northeast. The sharp decline is the result of landfills either reaching their capacity or closing because they do not meet county, state, or federal landfill standards, which increase the cost of designing, running and closing landfills (Ackerman 1997; Kovacs 1993). New landfill regulations cause existing landfills to fill up quickly. For example, government regulations typically require that each day's garbage must be covered with at least six inches of soil, which consumes as much as $30 \%$ of landfill capacity. 
Communities and private waste companies have been searching for new places to bury their garbage. Some poorer distant local communities may be willing to take tremendous amounts of garbage in exchange for significant money. States and local governments are almost powerless to stop the flow of garbage across their borders (Kovacs 1993; Wilt and Davis 1996; Ozgur 1998). One private waste disposal company had tried for many years to open a huge landfill in South Dakota that would hold nearly twice as much municipal solid waste as the entire state produces.

The sanitary method of landfilling was first developed in England during and immediately following World War I. In practice, many sanitary landfills were similar to open dumping. Land-based solid waste disposal seemed advantageous during the 1940s and 1950s, because of the relatively low cost of landfilling waste at those times in most part of the United States. There was easily accessible cheap land, which can be converted to a landfill with little initial cost at the outskirts of the growing cities and suburbs. Landfills had been established with little precaution and design requirement in the abundant undeveloped land at the outskirts was thought to handle any amount of garbage generated in the cities until 1960s (Blumberg and Gottlieb 1989, 16). It has been suggested that earlier sanitary landfills in the United States were neither sanitary neither in original conception nor in final management. The first sanitary landfills in the US were established in New York City and in Fresno, California in the 1930s. By 1940, the Army had begun research and experimentation in this area. Five years later, nearly 100 municipalities had either developed or initiated plans for a sanitary landfill.

Surveys during the 1950s by the American Public Works Association and the United States Health Service indicated that less than $50 \%$ of the Americans living in cities with approved sanitary and nuisance-free methods refuse disposal (APWA --American Public Works Association-- 1961, v). During 1950s and 1960s, sanitary landfilling was seen as a method based on the principles of engineering capable of eliminating any hazards to public health or safety as opposed to simply burying the wastes without any additional intervention. The goal of sanitary landfilling was to minimize the health concerns associated with open dumping used worldwide as a waste management method for centuries (Blumberg and Gottlieb 1989, 16-17). However, sanitary landfills are not a final solution to solid waste disposal in spite of its relative safety. During 1960s and early 1970s, the emphasis on technology enormously strengthened the position of sanitary landfills over open dumps, by focusing on the health and environmental impacts of both open dumps and earlier landfills. Congress enacted the RCRA of 1976. The RCRA, its amendments, and related USEPA regulations arranged the rules for construction and operation of solid waste landfills to eliminate open dumps and reduce pollution. Now, landfill requirements are more stringent.

The sanitary landfills were thought environmentally benign and safe for public health. They were seen as a real alternative to open dump. Yet the sanitary landfill never really had a chance to establish itself as an alternative to open dumps. By the late 1970s and early 1980s, the focus on landfill problems extended to all sites, including those that met the new and more stringent standards, such as clay caps and liners to prevent leaching of the wastes into the groundwater. To provide better pollution control, all new and expanded landfills are required to be constructed with a liner, a leachate collection system, a landfill gas control system, and a groundwater monitoring system. Once a landfill is full, the owner/operator must carry out the landfill's closure plan previously submitted to the state. Subtitle D requires that: (1) Closure plans must include activities to properly close the landfill and monitor and care for it 
for at least 30 years after closure. (2) Closure plans must include covering the landfill with soil (Murphy 1993, 95-96).

Because of stricter landfill regulations, thousands of landfills were closed. The solution seemed to be fewer but larger landfills; in relative terms, giant dumps are cheaper to build than small ones. Wilt and Davis (1996) claim that strict rules about landfill safety have created good business opportunities for multi-million dollar waste companies instead of relieving environmental pressures. Multi-million dollar waste companies offer desperate communities large landfills in exchange for some money. The private sector entered into municipal solid waste collection and street sweeping business with municipalities in the late nineteenth century. Private sector investments in solid waste disposal and recycling are more recent. Municipal solid waste disposal became a profitable and attractive business in the 1980s for private companies when the RCRA and its amendments became effective.

Widespread recycling has been implemented during several different periods in the United States. During the 1940 s about $25 \%$ of the waste stream was recycled and reused. During the environmental movement between 1968 and 1978, recycling was seen as the way to conserve energy and improve the natural environment (Everett 1989; Melosi 1981). Spurred by concerns for the environment, the country's recycling and composting rate rose from $7 \%$ in 1960 to $17 \%$ in 1990 (USEPA 1996). The 1990 State of Garbage Survey by Biocycle (Glenn 1990), which had data for 1989, reported that the recycling rate was $8 \%$ and the landfilling rate was $84 \%$. State of Garbage in America survey shows a $28 \%$ recycling rate and a $62 \%$ landfilling rate for 1996. There were 600 recycling programs, most of which took place in New Jersey and Pennsylvania in 1988. The number of recycling programs has increased to 6,600 in 1995. Landfilling of municipal solid wastes declined to $67 \%$ in 1994 from a high $84 \%$ in 1990 (Steuteville 1995). The contribution of alternative disposal methods has been increasing, whereas the role of landfilling has been decreasing since the early 1980s.

Solid waste recycling is an especially attractive strategy for state and local officials because of its potential to reduce disposal costs, conserve available landfill capacity, and contribute to national goals of energy and resource conservation (Ackerman 1997; Folz 1991, 222; Folz 1995; Kreith 1994). Many recyclable materials are however not valuable, and some others have low value. For these reasons, few recycling programs can now pay for themselves through materials sales alone. The real economic advantages of recycling stem from the disposal costs that recycling helps to avoid (Denison and Ruston 1990, 11). Recycling is not easily increased especially after a peak (ideal) recycling rate (around $25 \%$ ) achieved.

The first purpose of this paper is to examine the reasons why American federal government and all US states try to reduce land-based solid waste storage and disposal at various degrees. Alternative federal and state municipal solid waste disposal policies and programs are incorporated into the history of solid waste regulation in the United States during the 20th Century. History of solid waste disposal practices by cities and states and regulations by states and federal government as well as examination of important solid waste disposal issues help to understand the underlying reasons of reducing land-based solid waste disposal in the US starting from mid-1960s and heightened during 1980s and 1990s.

American states exhibit a significant amount of variation in the MSW landfilling rates, making this policy area an excellent laboratory exercise for various comparative and historical policy analyses (Lester, 1994; Ozgur, 1998). State programs must meet federal minimum requirements, but few barriers prevent states from creating regulations that exceed these standards. During 1980s and 1990s, United States Environmental Protection Agency (USEPA) 
believed that a $25 \%$ recycling rate is optimal. While few states had less than a $50 \%$ landfilling rate, few others had more than a $90 \%$ landfilling rate till late 1990s. The share of recycling, source reduction, composting and incineration are in significant increase against land-based sanitary landfilling of MSWs.

Let start to answer to the main research question, which is why and to what extent do states restrict land-based municipal solid waste disposal. Examination of issues and regulations of land-based solid waste disposal provided some useful background. The history of landbased municipal solid waste disposal policies, regulations, practices of federal and state governments in the USA are also discussed. Historical development of sanitary landfilling and incineration also are summarized. The relationship between solid waste practices and federal and state regulations are two-way: Solid waste practices impact regulations, and federal and state regulations cause changes on solid waste practices and technology. The most effective and important of various federal regulations concerning solid waste disposal seem to be the Resource Conservation and Recovery Act (RCRA) of 1976 and its amendments. Therefore, regulations of solid waste management are divided into two main time periods as discussed below --before and after the RCRA.

\section{6}

\section{Major Federal and State Solid Waste Disposal Regulations before the RCRA of}

The modern conception of solid waste management first emerged in the 1890s under the influence of the sanitary reform movement and the municipal reforms associated with the Progressive Era. The sanitary problems generated by the rapid industrialization and urbanization of the second half of the nineteenth century got attention from the Progressive Era reformers. Reformers in many urban centers began to lobby for municipal control over the collection of urban wastes. Prior to that point, waste had been viewed largely as an individual rather than governmental responsibility.

The first limited governmental intervention on solid waste collection and disposal in the United States started in Washington D.C. in 1795: The Corporation of Georgetown (Washington D.C.) enacted a law prohibiting the disposal of garbage in the streets assuming individual responsibility rather than governmental responsibility. This law required individuals to either carry away garbage themselves or to hire a private carter. In 1800, President John Adams hired a private carter to haul garbage away from the White House, but it was not until 1856 that Washington had a city wide garbage collection system supported by taxes (White 1983). Neither of these early laws requiring garbage collection nor regulations in the first half of the twentieth century later influenced solid waste disposal.

Consistent with lack of governmental intervention to solid waste collection and disposal, as late as 1880 , according to census figures, only $43 \%$ of all cities provided some minimum form of collection. In other words, more than half of the American cities had no systematic garbage collection. Lack of public intervention to the steady accumulation of garbage in the streets reportedly inhibited the development of the U.S. disposal technologies in contrast to those Europe during the late nineteenth and early twentieth centuries in spite of pressure by higher per capita generation of waste in the United States (see Blumberg and Gottlieb 1989, 5-6). Despite the high generation of waste, unreliable waste disposal technologies, and efforts of reform movement advocates, more than half a century was needed to take precautions and focus on problems of waste disposal issues. 
Starting with 1880, municipal reform advocates discussed the issue of whether or not solid waste collection and disposal was the responsibility of any government. Advocates of the reform movement focused on efficiency and importance of governmental intervention on municipal solid waste collection systems. With the influence of home rule provisions, more cities accepted the responsibility for waste collection and disposal as part of their municipal function. Melosi (1981, 232-237) noted that municipal authorities actively discouraged state legislatures from interfering in sanitation services and especially tried to gain and maintain control over city health departments. Municipal discouragement of state intervention deferred state involvement in solid waste collection and disposal for several decades.

The first major federal government intervention in solid waste disposal started in the middle of the 1960s. Involvement of states in solid waste disposal started one decade later just before the enactment of the RCRA of 1976. During the 1980s, virtually all states had established rules and regulations about solid waste disposal due to the requirements of various federal statutes. Not only state involvement, but also federal government initiatives in solid waste management, was very limited until the middle of 1970s. Early federal regulation of waste disposal (1899 and 1908) was based on the concern of the need for navigable waters for ships but not on the health and environmental impacts of dumping waste in rivers and oceans.

By the turn of the century, a variety of waste disposal practices were adopted by municipalities, ranging from land and water disposal (including ocean dumping) to incineration, reduction, or some combination of these methods. Among the disposal methods water and ocean dumping were heavily criticized because they caused pollution of surface waters not only in the community where waste was disposed, but also in neighboring and downstream communities. Advocates of the public sanitarian movement emphasized possible public health impacts, while the federal government was basically concerned with safe navigation. Finally, the practice of ocean dumping of municipal solid wastes was banned in 1933. Industrial and commercial wastes continued to be dumped into the oceans. Identifying streams and other water sources as nature's sewers was justified by economic interests. Municipal officials and engineers could not stand against economic interests (Blumberg and Gottlieb 1989, 7).

Most sanitary engineers preferred either incineration or reduction as major disposal methods, hesitating to use land-based disposal methods because of apparent negative health and environmental effects. Blumberg and Gottlieb (1989, 7-16) reported that sanitary engineers dominated waste management decisions from 1890 to the 1930 s. The garbage issue, appeared to be under control during the 1950s and 1960s, seemed to be reviewed by sanitary engineers, municipal officials, and other policymakers. From the beginning of the World War II to 1965 , saliency of the garbage issue was low, and little attention was paid to solid waste disposal by any governmental institutions or officials.

A report issued by the Bureau of Solid Waste Management indicated that the rising urban population and entrance of new chemicals into the waste stream during the $1960 \mathrm{~s}$ resulted in hard-to manage problems. The expertise and knowledge of sanitary engineers and capabilities of municipal governments were inadequate to solve these problems. The waste handling resources and facilities of most of the communities in the nation could not address the problems due to increasing cost of urban land, early signs of negative public reaction (Rasmussen 1992), and technological shortcomings of the disposal methods. Increased generation of wastes and the hazards of both land-based and incineration waste disposal methods were emphasized during the 1960s. According to the Bureau, $94 \%$ of all land disposal 
operations and $75 \%$ of incinerator facilities were clearly inadequate in terms of air and water pollution, insect and rodent problems, and physical appearance. Thus, open dumping and incineration were of particular concern (Blumberg and Gottlieb 1989, 17).

The growing complexity of the solid waste problem and the issue of responsibility for solid waste management forced many cities to get help from federal and state governments. The federal government's increasing interest in the waste problem became noticeable in the 1960s. Before that time, it had been restricted to a small group of researchers in the Public Health Service, who conducted modest investigations on the relationship of sanitation services and public health. These researchers also provided information to the military for developing programs about disposal of wastes at federal installations (APWA 1976, 453).

As a response to early concerns rose during the 1960s about solid waste disposal, the 1965 Solid Waste Act became law, but had little impact on waste management in any level of government. Until 1969, the role of federal government in environmental policymaking was sharply limited with the exception of public land management. Air, water, and land pollution, which were considered strictly a local matter, were not prominent issues on the agenda of national government and states. Solid waste disposal emerged as a significant national problem when it was linked with air and water pollution.

In 1965, the solid waste disposal issue received better recognition by federal government. In a special message on conservation and restoration of national beauty, President Lyndon B. Johnson called for a better solution to the disposal of solid wastes and recommended federal legislation to assist state governments in developing comprehensive disposal programs and to provide research and development funds. Following his recommendation, Congress passed the Solid Waste Disposal Act of 1965 --interestingly, as Title 2 of the 1965 amendments to the Clean Air Act. The Disposal Act recognized the evermounting volume and changing character of waste. It also noted the inability of current methods to deal with the problem and the failure of resource recovery programs to convert waste into usable byproducts (Melosi 1981, 199-200).

The primary thrusts of the Act were to initiate and accelerate a national research and development program and to provide technical and financial assistance to state and local governments to create interstate agencies for the planning, development, and conduct of disposal programs. The Solid Waste Disposal Act represented the first significant recognition of refuse as a national issue focusing primarily on disposal of waste rather than collection or street cleaning. Not satisfied with legislation alone. President Johnson, with the advice of his Scientific Advisory Committee, directed that a special study be made of the nation's solid waste problem. As a result, the 1968 National Survey of Community Solid Waste Practices was produced.

To refine the 1965 Act, Congress passed the Resource Recovery Act in 1970. This Act provided two important contributions or changes as compared to the 1965 Act. First, it shifted the emphasis of federal involvement from disposal to recycling, resource recovery, and the conversion of waste into energy. Second, it stimulated a national system for storing and disposing of hazardous wastes (Melosi 1981, 201). Subsequent laws, such as the Resource Conservation and Recovery Act of 1976, were built upon the 1970 Act. Federal legislation passed in 1965 and amended in 1970 with new provisions gave the federal government a clearly defined role for the first time. The federal government, then, began to support projects and research for the development of the new technologies regarding storage and disposal of hazardous and solid wastes (Blumberg and Gottlieb 1989, 18). 
The administrative structure established to oversee the implementation of the federal refuse program was as important as the new legislation. At first, too little attention was given to this aspect of federal involvement, and responsibility was passed from agency to agency. USEPA, created in 1970, assumed responsibility for most hazardous and solid waste activities. Therefore, a single headed agency, created exclusively to manage environmental issues, raised expectations to solve the waiting problems of waste management. In the 1970s the Office of Solid Waste, a department of the USEPA, acquired the authority to conduct special studies related to solid waste, to award grants, and to publish guidelines (APWA 1976, 453; Melosi 1981, 201). Although the establishment of the Office of Solid Waste provided a degree of stability and permanence for federal solid waste programs, in the mid-1970s the USEPA proposed a drastic cutback in the federal solid waste program and recommended that federal activities be limited to regulating hazardous wastes. This caused opposition from Congress, state, and local groups. As a result, USEPA announced its willingness to continue to develop and promote resource recovery systems and technology (Melosi 1981, 202).

At the time of the passage of the Solid Waste Disposal Act of 1965, there were no statelevel solid waste agencies in the country, and only five states had employees are assigned to any phase of solid waste management. Four and a half-years after the first grant of technical assistance was awarded, forty-four states had active programs (Van Tassel 1973, 468). Blumberg and Gottlieb $(1989,19)$ mentioned that "partly as a result of growing community pressure, some limited local and state measures such as packaging review ordinances were developed to address the extraordinary growth of the waste stream". However, these local and state measures were criticized heavily by legislatures. A strong counterattack by the packaging, petro-chemical, and beverage container industries led to an important modification of these measures. Industry and government officials made some criticisms about production choices, placing responsibility on the individual consumer. This concept of blame the victim was emphasized by one of the advocates of environmental legislation, Edmund Muskie (D Maine), a prominent Senate environmental leader during the late 1960s. Muskie, who helped steer the 1970 solid waste legislation, the Resource Recovery Act, through Congress, wrote that "it was easy to blame pollution only on the large economic interests, but pollution is a byproduct of our consumption-oriented society. Each of us must bear his share of the blame" (Blumberg and Gottlieb 1989, 20). Also, the traditional conservationist groups and even many of the newly emerging environmental organizations attacked the individual choice of consumption and increasing population because it was considered the main cause of solid waste problems.

The turning point in solid waste regulation was the 1976 Resource Conservation and Recovery Act (RCRA) and its 1980 and 1984 amendments. The RCRA created interest and pressure at all levels of governments. With the impact of the RCRA and other stringent federal and state regulations, states started to play a major role in solid waste management with an emphasis on contamination of water, preservation of landfill space and promotion of recycling efforts. States are strong policy makers in solid waste management. There are several indicators and reasons. First of all, a majority of the oversight, implementation, funding, research, and planning of solid waste regulation (policies) take place at the state level. Second, several use the discretion afforded by solid waste statutes. Finally, states often have significant environmental and solid waste programs and responsibilities of their own, separate from those required by federal enabling legislation (Ringquist 1993, 3). As mandated by the RCRA, states have considerable responsibility in the design of policy approaches to the management of 
waste. This new federal-state relationship is called "centrally directed sharing". States are leading the way in solid waste reduction and recycling. In fact, the plethora of state laws has led some polluters to seek help from the federal government to standardize (and weaken) the mishmash of rules they face. For example, merchandisers of so-called "biodegradable" or earth friendly products are so troubled by the assortment of rules emerging from state capitals that they are lobbying the Federal Trade Commission to set national guidelines for what the labels mean.

The implementation of federal environmental regulations, including solid waste, is generally given to the states. In the era of increasing and stringent environmental regulations, landfill closures, problems of incinerators, and declining federal grants, states and localities are forced to take responsibility for solid waste management with limited economic resources. During the 1980s, fiscal resources to manage new environmental responsibilities from federal government declined while responsibilities increased. At the beginning, most states, except few like Wisconsin, Rhode Island, Oregon and New Jersey, resisted to raise funds to solve solid and other waste issues Starting with mid the 1980s, most states have taken more responsibility and created new policies. In general, state environmental and solid waste commitment has increased greatly since the 1970 s.

Decentralization of federal environmental programs and the amount of federal money given to states as environmental grants-in-aid have been declined instead of increased. Thus, state environmental management in the 1990s largely was governed by two considerations that are internal to the states themselves. The first concern is the level of state institutional capability. The second concern is the level of state commitment to environmental protection including solid waste. While federal and local influences cannot be disregarded, these withinstate influences are very helpful in understanding what the states have done in the area of environmental management (Lester 1990, 72). Significant solid waste policy, funding, staffing, and commitment differences exist at the state level.

Despite the fact that prior to the enactment of the RCRA in September of 1976 there were several federal statutes concerning solid waste, none of the statutes mandated or offered any guidance as to how solid waste problems could be managed. Hazardous wastes were not a major concern in the Solid Waste Disposal Act. In addition, Section 208 of the Federal Water Pollution Control Act (1972) affected solid waste planning through water pollution control activities authorized by the Act (Kovacs 1986, 9). The Solid Waste Management Act of 1965, as amended by the Resource Recovery Act of 1970, provided technical and financial assistance to state and local governments in the planning and development of resource recovery and other solid waste disposal technologies. Such legislation affirmed reliance on local and state action for coping with solid waste problems.

As Kovacs $(1986,9)$ noted that "by 1975 the incentives provided under the Solid Waste Disposal Act and the Water Pollution Control Act encouraged 48 states to adopt some form of solid waste management program." He also reported a greater difference in state programs in terms of staffing (from few to many persons) and operation budgets (ranging from zero dollars to 1.2 million Dollars). By mid-1975, all the states but Wyoming had enacted solid waste management legislation to comply with federal law. As a result, solid waste was no longer an exclusively local issue. The involvement of state and federal governments began to offer hope for directing expenditures of fronds, research and administrative activities in a more comprehensive way. At the same time, it also led to confused and complicated questions of jurisdiction and responsibility for collection and disposal (Melosi 1981, 202-203). To resolve 
this issue, Congress passed the 1976 Resource Conservation and Recovery Act, which created a federally imposed cooperative federalism in waste management.

\section{Major Federal and State Solid Waste Disposal Regulations after the RCRA of 1976}

The 94th Congress was approached by municipalities, as well as environmental, public interest, and industry groups about the lack of landfill capacity and its impact on municipal government, environmental protection, and industrial expansion. The problem was not viewed as an immediate threat to public health and safety, but rather as a future threat to the health of the nation. In the past twenty years, a substantial body of state and federal legislation regulating the disposal of industrial, hazardous, and municipal solid wastes has been developed. Before that time, solid waste management was based on the judgment and decision of individuals or local health and sanitation departments. No distinction was made between industrial and municipal solid wastes. Significant federal regulations governing the disposal of nonhazardous and hazardous waste did not go into effect until 1976. Concerns for human health and the environment were the impetus for the enactment of the major federal legislation --the Resource Conservation and Recovery Act of 1976.

During the crafting of the RCRA, Congress knew that it had the opportunity both to regulate disposal methods and to reduce the generation of waste by regulating production and products. Several bills were introduced to minimize waste by regulating product contents, consumer product packaging and manufacturing processes; however, these bills did not pass. Congress gave substantial power to states for solid waste policy making and implementation since many bills, which would reduce the role of states, failed to pass.

Congress highlighted important findings about land-based solid waste disposal when the RCRA was amended in 1984. The new federal legislation was based on the following findings: (1) New methods of manufacturing, product packaging, and marketing were increasing the amount and changing the characteristics of solid wastes. (2) Economic and population growth, together with a rising standard of living, was increasing industrial production and the need for new construction, resulting in increases of scrap material. (3) The concentration of populations was creating financial, managerial, intergovernmental and technical problems in the disposal of solid waste. (4) While the collection and disposal of solid waste is a function of the states and localities, the problems identified have become national in scope requiring federal assistance (RCRA of 1976, U.S. Code 1988, Title 42, section 6901).

The Congress found, with respect to the environment and health, that: (1) Most solid waste is disposed of in sanitary landfills or open dumps. (2) Disposal of solid waste in the ground can be harmful to human health and the environment if not managed properly. (3) The Clean Air Act and Water Pollution Control Act have created greater amounts of solid wastes that have not been properly disposed of in many cases and have ultimately led to greater amounts of air and water pollution. (4) Open dumping is harmful to health by contaminating drinking water supplies above and underground. (5) Improper disposal of hazardous wastes could result in considerable harm to health and the environment. (6) Alternatives must be found for solid waste disposal because many cities are running out of suitable disposal sites (RCRA of 1976, US Code 1988, Title 42, section 6901).Congress also found, with respect to materials and energy that: (1) Millions of tons of recoverable materials are unnecessarily buried each year. (2) Methods are available to separate solid waste from usable material. (3) 
Recovery and conservation of such materials can reduce United States dependency on foreign sources. (4) Solid waste represents a potential source of fuel. (5) Alternate energy sources can reduce our dependence on fossil fuels, nuclear, and hydroelectric energy. (6) Technology exists to produce usable energy from solid waste (RCRA of 1976, US Code 1988, Title 42, sec 6901). With these findings, the act proposed to assist in developing and encouraging environmentally sound methods for the disposal of solid waste. It also proposed to maximize the utilization of valuable resources including energy and materials, and to encourage resource conservation. These objectives were to be accomplished through federal technical assistance to states or regional authorities for comprehensive planning pursuant to federal guidelines designed to foster cooperation among federal, state, local governments, and private industry (RCRA of 1976, US Code 1988, Title 42, sec 6902).

"Several agencies and organizations, including NSWMA, USEPA and the Federal General Accounting Office (GAO) (1995) have surveyed state regulatory agencies to determine the number of existing landfills. Data collected by NSWMA from 1988 to 1991 showed that landfill numbers ranged from a high of 7,575 in 1988 (using GAO data) to a low of 5,368 (using NSWMA data). Individual state data evidenced a wide variability between surveys that could not be attributed to normal year-to-year variances. For example ECON magazine reported in 1991 that California has 1,012 landfills, while NSWMA data reported only 344 for the same year. Some of the variability in the data can be attributed to landfill closures and openings. ... one can only speculate about the causes" (Repa and Blakey 1996).

According to Wilt and Davis (1996), the main focus of the RCRA is the resource and energy lost in the disposal of garbage and the need to upgrade open dumps to sanitary landfills. The second main objective of the RCRA's landfill provision is to protect human health and the environment. To achieve the second goal, a landfill management plan must include steps to properly monitor the landfill while it is operating and must maintain the facility for at least 30 years after it is closed. Landfill owners also must show that they have the means to finance closure and post-closure care of the landfill as well as the cleanup of any leaks.

One of the goals of the RCRA's prohibition on open dumps is to raise the cost of landfills to a point where resource recovery and recycling activities could be competitive. Since 1976, Congress intended USEPA to vigorously regulate land disposal for the goal described above. However, between 1976 and 1984, USEPA did little to increase the cost of land disposal. Therefore, in 1984, Congress, mistrusting of USEPA's ability to regulate land disposal to protect health and the environment, amended the RCRA to prohibit many wastes from being disposed of land unless USEPA established that such disposal did not present harm to human health and the environment (Kovacs 1986, 24). These new amendments facilitated landfill closures and promoted nationwide recycling practices as expected. Another important goal of the RCRA is to require each federal procuring agency with respect to any procurement in excess of $\$ 10,000$, to procure items composed of the highest percentage of recovered materials practicable. USEPA is required to provide each federal agency with information on the availability, sources of supply, and potential uses of materials recovered from solid waste.

As the principal national law regulating the management of solid waste, the RCRA is designed to encourage communities to manage solid and hazardous wastes in an environmentally sound manner that maximizes the use of valuable resources, including energy and materials recoverable from solid waste. Under Subtitle D of the RCRA, the federal government is responsible for setting criteria and minimum technical requirements for environmentally sound disposal facilities, while states are responsible for enforcement 
(Starkey and Hill 1996, 4-5). By design, the RCRA does not provide for a comprehensive federal regulatory role in municipal solid waste management. Therefore, states have passed regulations for landfills and incinerators and have set recycling goals. Federal government may play important roles in solid waste management, including recycling requirements, incinerator restrictions, flow control, stopping subsidies for virgin materials, procurement policies, and a national bottle bill (Murphy 1993, 6-7).

There was no guidance at the federal level for the workability of technology or technical assistance in the planning aspects of solid waste management. The only federal incentive in the planning aspects of solid waste planning is the issuance of industrial development bonds. Federal government has little incentive and willingness to get back into the solid waste business (Kovacs 1986, 22); therefore, states and industry manage solid waste problems under federal provision and regulations. States do not directly manage solid waste collection. However, few states like Delaware involve directly in solid waste disposal by having regional landfills. Local governments and the private sector achieve the actual solid waste collection and disposal.

Kovacs $(1986,19)$ described USEPA's implementation of the RCRA as fragmented and inconsistent. Similarly, regarding nonhazardous solid waste regulation of the RCRA, Goldsteen $(1993$, 181) postulated that enforcement authority is generally not strong and legislation limits the federal role to establishing minimum criteria for the best practical controls and the monitoring requirements for solid waste disposal facilities. USEPA has separately managed the Subtitle C hazardous waste program of the RCRA as if it is not related to the Subtitle D solid waste program (Kovacs 1986). When Congress enacted the RCRA in 1976, it established separate authorities for Subtitle D Solid Waste Management Planning Programs and the Subtitle C Hazardous Waste Management Programs.

In the Subtitle D programs, each subsequent year's authorization for the program was diminished because Congress considered solid waste management as a state and local function. The federal role was to give the states the seed money for solid waste planning and a time period to establish their own mechanism to implement an approved solid waste plan. From the date of enactment of the RCRA, state and local governments realized that they were responsible for implementing their solid waste plans and to generate their own funding. In the Fiscal Year 1983 budget, there were no federal funds appropriated for solid waste disposal.

Through the decade of the 1970s, various environmental and health issues of solid waste disposal, particularly contamination of the land through landfills, became a central issue that contributed to the growing solid waste dilemma. In addition to environmental problems, managerial problems associated with landfill closures and capacity issues made USEPA's Office of Solid Waste Management one of the largest parts of the mushrooming environmental bureaucracy of the 1970s. This Office is basically devoted to reviewing and dealing with the problems of land disposal sites (USEPA 1973).

Without occasional USEPA review, the state planning authorities were free to implement whatever projects they wished. States are left to their own discretion as to the implementation of their solid waste plans. Such a lack of discretion from the federal government provided states with freedom to develop their own solid waste management practices. Therefore, each state can utilize a different approach to solid waste planning, or a combination of approaches. Freedom of states to develop solid waste plans has resulted in innovative and experimental solid waste practices. For example, the state of New Jersey, to preserve landfill space before getting its waste to energy facilities on line, established a 
recycling allowance in which local municipalities receive a rate from the state based upon the amount of materials recovered. New Jersey policymakers believed that their remaining landfill capacity could be economically extended (Kovacs 1986, 22). Some states, like Pennsylvania and New York, have stricter regulations as compared to the requirements of the RCRA. In states requiring major revisions in their regulations, the changes may affect future costs for building, operating, and maintaining landfills. As with incineration, state officials and landfill owners and operators must keep one step ahead of regulators definition of "state-of-the-art" and anticipate future requirements.

Most of the practitioners and legislators in solid waste management see recycling as a promising alternative to reduce landfilling rate. The extent of local and state recycling programs affect state landfilling rate. Few political scientists working in environmental regulation field seem to believe that truly effective environmental regulation is very unlikely, if not impossible (Bardach and Kagan 1982; Lewis-Beck and Alford 1980; Rasmussen, 1992). A small group of other researchers like Evan J. Ringquist (1993; 1994) believe that regulation does work. Particular federal and state solid waste management regulations affect both directly and indirectly a state's landfilling rate. Higher recycling rates at reasonable cost and ease cannot be achieved only by relying on disposal bans.

Due to the closure of many landfills, regional disposal facilities have been gaining importance. More than 40 states have actively promoted regional solid waste management through legislation. In general, the regional organizations outside the Northeast have failed to carry out their plans because of inadequate financing mechanisms. However, in the face of rapidly diminishing landfill capacity, regionalization helps to keep regional capacity long enough and tipping fees reasonably low (Tennes 1995; Waters 1993).

Regional facility development in the Northeast was inspired from perceived and actual need for alternative disposal options. Consequently, local governments were willing to use a variety of financing mechanisms to answer increased demands. In contrast, regionalization efforts in much of the rest of the country have focused on planning efforts for compliance with the RCRA Subtitle D standards and other requirements (Craggs 1995). In various regions of the United States, regionalization as the collective management of waste services by more than one municipality has evolved to represent a variety of approaches. These approaches include partnerships between a county and the cities within its jurisdiction, a collective venture of several cities, or a group composed of county governments. Regionalization is believed to provide direct and indirect benefits to local governments. The primary benefits include economies of scale, shared liability, and minimization of siting and permitting constraints and shared resources (Craggs 1995; Starkey and Hill 1996). Regionalization of waste management are also discussed for other geographies, like Romania (Mihai, 2013).

Many states now require some form of solid waste plans, which include the identification of alternative approaches to promote long-term viability. Indiana, Missouri, and Ohio created regional solid waste districts responsible from planning and disposal with special legislation. California created special service districts that are limited-purpose governmental units responsible for sanitary services including solid waste disposal (Craggs 1995). Regionalization of solid waste disposal is seen as helpful to achieve economies of scale, increase efficiencies in service delivery and spread fixed costs (Belue et al. 1997). The costsensitive nature of most waste management facilities may continue to create pressure for fewer but larger regional facilities (Williams 1994, 2.4). 


\section{Conclusion}

Trust in technology is high in the United States. This concept is not new in the United States and its root can be found in the municipal reform movement. Within the last hundred years, the United States has faced several solid waste collection and disposal crises. Several so called state-of-the-art initiatives, designs, and programs were offered as permanent solution to the solid waste disposal issues. As Melosi (1981) demonstrated that a solid waste disposal crisis cycle is seen in the United States every 15 to 30 years. Policies, standards, and programs should consider specific characteristics of the region or state and suitability of particular disposal technology for that region. Instead of trusting a particular technology like incineration as the ultimate solution to the wastes and for all times and all regions, alternatives should be sought, and expectations from technology should be lowered.

During the 1970s, because of growing discontent and leachate problems around landfills, a new terminology arose to signify the new hopes: "resource recovery". It evoked the old Progressive dream of capturing part of the waste stream in some new form. This included recycling concepts, or materials recovery and, most significantly, to many of the public officials and waste industry executives, energy recovery linked to the burning of waste. The latter, known as "waste-to-energy" or "refuse-to-energy" (Communication Channels Inc. 1994) was little more than a variation of an old theme: Bum it instead of burying it (Blumberg and Gottlieb 1989,21). With the addition of the source reduction concept, USEPA's disposal hierarchy looks like a modified version of this old Progressive dream although USEPA has never implied or expressed it.

Landfills that meet federal standards can lessen environmental risks. Subtitle D of the RCRA 1976 requires landfill owners and operators to monitor water sources and to maintain a leachate collection system and a final cover for a minimum of 30 years after the landfill closes. This long-term maintenance requirement is critical, since even the most well designed landfills may eventually fail due to the natural deterioration of liners, leachate collection systems, and final cover materials (Starkey and Hill 1990, 16-17). Modern landfills are relatively safer. However, despite safer and newer technology, more than $20 \%$ of the 1,200 cleanup sites on the Superfund National Priority List are landfills. Modem landfills are not environmentally benign, but technical improvements made in landfill design and operation, combined with today's stricter standards, have lessened their negative environmental impacts. Improvements in landfill design and technology have not made siting a landfill easier. Contrary to the general belief that siting landfills is getting more difficult, Murphy (1993, 9495) claimed that newer and safer technology has helped to renew public confidence in this waste disposal option.

Siting a disposal facility, particularly a landfill, is an increasingly difficult challenge due to public reaction (Rasmussen 1992) and distrust to technology. Moreover, the technical constraints and regulatory standards are big hurdles in themselves --and the political issues involved are particularly volatile. The siting of new landfills also is hampered by the poor environmental track record of older dumps. Before a landfill is constructed, an environmentally appropriate and politically acceptable site must be selected. Federal regulations help to guide communities in this process by creating specific requirements to improve the siting, design, and operation of new landfills. The RCRA's Subtitle D restricts the siting of landfills in flood plains, wetlands, earthquake prone areas, near airports, or where the ground cannot support the weight of a landfill. State and local governments can influence the 
selection of a site by requiring building permits, regulating the landfill size, and enforcing zoning ordinances. Landfill design criteria also are outlined in the new regulations.

New federal legislation to protect the environment has increased the cost of building new landfills. Moreover siting landfills has become increasingly difficult because the public opposes having such a facility nearby. The sharp decline is the result of landfills either reaching their capacity, or closing because they do not meet state or federal landfill design and operation standards. Many of the smaller local landfills have been closed; however, larger active private and public landfills provide enough capacity in most of the country, so that the country's overall landfill capacity is not declining. Transporting waste to larger regional facilities and uneven distribution of landfill capacity are the major problem. The closure of landfills and opening new large regional landfills, however, raise questions. It may be easier to site and build a landfill in the open spaces of New Mexico than in crowded New Jersey, but that does not help communities in the Northeast faced with decreasing landfill capacity unless they are willing to pay high transportation costs. It does not address the fact that people who live in those open spaces do not want to be the dumping grounds for other people's garbage (Murphy 1993, 94).

Goldstein and Glenn (1997) claimed that the solid waste disposal crisis of the late 1980s and early 1990s has vanished based on the information gathered by yearly "State of the Garbage Survey" of 50 states. Their survey shows that most of the states report adequate landfill capacity; and the national average landfill tipping fees had actually declined. Survey also shows that growth in recycling and composting programs was leveling out. Another sign that the crisis ended is the minimal number of solid waste management laws coming out of state houses across the country. Bills that have passed primarily target specific waste streams or make minor changes to existing laws.

The intent of Subtitle D and 1991 guidelines is not only to protect the environment and ensure public health by closing unsafe landfills but also to encourage the public to utilize methods other than landfilling for the disposal of solid wastes. It is expected that disposal costs will increase because of closure of landfills due to Subtitle D and other stricter state regulations. If disposal costs go significantly higher, then recycling and source reduction is expected to increase, and landfilling to decrease (Kimball 1992, 9). This study confirms that restricting the amount and toxicity of municipal solid wastes that goes to landfills is an important consideration for many states. Federal government and states restrict land-based disposal of municipal solid wastes due to increasing cost of solid waste handling and storage, landfill closures, health and environmental issues of landfills and public reaction.

On the other hand, Goddard (1995) claimed that waste management problems are still viewed as technological deficiencies requiring engineering 'end-of-the-pipe' solutions. Others offer holistic or hypothetical solutions disregarding all aspects of solid waste disposal issue. For example, Wiseman (1991) estimated that at the current rate of solid waste generation, the nation's solid waste for the next 500 years could be buried in a single landfill 100 yards deep, 20 miles a side. A large region of Western South Dakota is seen as a perfect geological location for landfilling of solid wastes (Lehr 1991). Similar to Wiseman, Lehr (1991) argued that if this western part of South Dakota becomes garbage site of the nation, solid waste disposal issues could be solved in a cheap and environmentally safe way. Large amounts of waste shipments to other states like South Dakota may downgrade the importance of recycling and source reduction. Shipment of larger amount of interstate of solid wastes also create conflict among the receiving and sending states and communities. 
Historical reviews of municipal solid waste disposal in the US show that past waste disposal practices, and technologies (their environmental and health impacts) determine how solid wastes are managed. Sometimes, it seems that not the level of solid waste disposal issues, but the perception of policymakers about the waste disposal issues determines newer federal, state and municipal solid waste regulation and practices. State and federal government solid waste disposal practices and regulations seem to be formulated to be counterattack to the previous unwanted impact of solid waste disposal. When policies are determined as a counterattack to an emerging issue, short-term, end-of-pipe solutions are promoted.

Solid waste disposal practices for more than a century have created land depletion, groundwater contamination, air contamination, nuisances, and other negative externalities regardless of technologies and designs applied. These continuous and increasing solid waste disposal issues become the basic concerns for state and federal governments in reducing landbased solid waste disposal. Higher economic capacity states are more likely to have lower landfilling rate. States experiencing more severe solid waste-related problems and having physical or demographic constraints are more likely to have lower landfilling rates.

\section{References}

1. Ackerman F., 1997. Why do we recycle?: Markets, Values and Public Policy. Washington D.C.: Island Press.

2. APWA (American Public Works Association) Committee on Refuse Disposal, 1961. Municipal refuse disposal, Chicago: Public Administration Service.

3. APWA (American Public Works Association), 1976. History of public works in the United States, Chicago, Illinois: APWA.

4. Bardach E., Kagan R., 1982. Going by the book: The problem of regulatory unreasonableness, Philadelphia: Temple University Press.

5. Belue, M., Newcombe G., Guilmette L., Horton T., Caldwell-Johnson, T. 1997. Talking trash: Five solid waste pros tell you what they think you should know, American City and County, Vol. 112, no. 11 , October, 40-55.

6. Blumberg L., Gottlieb R., 1989. War on waste: Can American wins its battle with garbage, Washington D.C.: Island Press.

7. Communication Channels Inc., 1994. Waste-to-energy in the United States: Socioeconomic factors a decision-making process, Golden, Colorado: National Renewable Energy Laboratory.

8. Craggs R., 1995. Regionalization: A solid waste solution, American City and County, 110, no. 9, August, 44-46.

9. Darcey S., 1992. Coping with the landfill crisis, World Wastes, 35, no. 5, May, 26-34.

10. Denison R.A., and Ruston J., 1990. Introduction. In Recycling and incineration: Evaluating the choices, eds. Denison, R.A., Ruston J., Washington D.C.: Island Press.

11.El-Fadel, M., Findikakis, A. N., and Leckie, J. O. 1997. Environmental impacts of solid waste landfilling, Journal of Environmental Management, Vol. 50, No. 1, 1-25.

12. Everett, J.W., 1989. Residential recycling programs: Environmental, economic and disposal factors, Waste Management and Research, Vol. 7, 143-152.

13. Folz, D.H., 1991. Recycling program design, management and participation: A national survey of municipal experience, Public Administration Review, Vol. 51, No. 3, May/June, 222-231.

14. Folz, D.H., 1995. The economics of municipal recycling: A preliminary analysis, Public Administration Quarterly, Fall, 299-320.

15. General Accounting Office, the United States, 1995. Municipal solid waste flow control: Summary of public comments, Washington D.C.: The USEPA.

16. Glenn, J., 1990. The state of garbage in America, Biocycle, March, 48-55. 
17. Goddard, H., 1995. The benefits of costs and alternative solid waste disposal policies, Resources, Conservation, and Recycling, Vol. 13, 183-213.

18. Goldsteen, J.B., 1993. Danger all around: Waste storage crisis on the Texas and Louisiana Gulf Coast, Austin, TX: University of Texas Press.

19. Goldstein N., Glenn, J., 1997. The state of garbage in America, part II, Biocycle, 38, no. 5, 71-75.

20. Hird, J.A., 1994. Superfund: The political economy of environmental risk. Baltimore: John Hopkins University Press.

21. Kimball D., 1992. Recycling in America: A reference handbook, Santa Barbara, CA: ABC-CLIO.

22. Kovacs W. L., 1986. Legislation and involved agencies, in The solid waste handbook: A practical guide, ed. Robinson, W.D., New York: John Wiley \& Sons, 9-30.

23. Kovacs W.L., 1993. Solid waste management: Historical and future perspectives, Resources, Conservation, and Recycling, Vol. 8, no. 1-2, January, 113-130.

24. Kreith F., 1994. Introduction, in Handbook of Solid Waste Management, ed. Kreith, F., New York: McGraw-Hill, Inc., 1.1-1.24.

25. Lawrence C.M., Khurana I.K., 1997. Superfund liabilities and governmental reporting entities: An empirical analysis, Journal of Accounting and Public Policy, Vol. 16, no. 2, Summer, 155-186.

26. Lehr J.H., 1991. South Dakota is the answer, what is the question?, Ground Water, Vol. 29, No. 3, May-June, 322-326.

27. Lester J.P. 1994. Comparative state environmental politics and policy: The evolution of a literature. Policy Studies Journal, Vol. 22, No. 4, Winter, 696-700.

28. Lester J.P., 1990. A new federalism? Environmental policy in the states, in Environmental policy in the 1990s, eds. Vig N.J., Kraft M.E., Washington D.C.: Congressional Quarterly Press.

29. Lester J.P., Franke J.L., Bowman A.O’M., Kramer K.W., 1983. Hazardous waste politics and public policy: A comparative state analysis, Western Political Quarterly, Vol. 36, no. 2, 258-285.

30. Lewis-Beck, M., Alford J., 1980. Can government regulate safety? The coal mine example, American Political Science Review, Vol. 74, No. 3, 745-756.

31. Lodge G.C., Rayport J.R., 1991. Knee-deep and rising: American recycling crisis, Harvard Business Review. 69, no. 5 (September / October): 128-139.

32. Melosi M.V., 1981. Garbage in the cities: Refuse, reform, and the environment: 1880-1980, College Station, TX: Texas A\&M University Press.

33. Mihai, F.C., 2013. Development of MSW collection services on regional scale: spatial analysis and urban disparities in North-East Region, Romania, AGD Environment \& Landscape, Vol. 7, No. $1,13-18$.

34. Murphy P., 1993. The garbage primer. New York: Lyons \& Burford; League of Women Voters of the United States.

35. Office of Technology Assessment (OTA), 1992. Facing America's trash: What next for municipal solid waste? Reprint, Washington D.C.: Congress of the United States, OTA.

36. Ozgur H., 1998. A comparative state study of reducing land-based municipal solid waste storage: Determinants, policies, and frameworks, The University of Texas at Arlington, School of Urban and Public Affairs.

37. Rasmussen T.H., 1992. Not in my backyard: The politics of siting prisons, landfills, and incinerators, State and Local Government Review, Vol. 24, No. 3, Autumn, 128-134.

38. Reese C.E., 1983. Deregulation and environmental quality: The use of tax policy to control pollution in North America and Western Europe, Westport, Connecticut: Quorum Books.

39. Repa E.W., Blakey A., 1996. Waste disposal trends, Waste Age (January): 43-54.

40. Ringquist E.J., 1993. Environmental protection at the state level: Politics and progress in controlling pollution, Armonk, NY: M.E. Sharpe.

41. Ringquist E.J., 1994. Policy influence and policy responsiveness in state pollution control, Policy Studies Journal, 22, no. 1: 25-43.

42. Starkey D., Hill K, 1996. A Legislator's Guide to Municipal Solid Waste Management, Washington 
D.C.: National Conference of State Legislatures.

43. Steuteville R., 1995. The state of garbage in America, part I, Biocycle, 36, 4 (April): 54-63.

44. Tennes A.E., 1995. Regional agency signs 20-year transfer contract, World Wastes, 38, no. 12: 14.

45. USEPA, 1973. Environmental assessment of gas and leachate problems at land disposal sites, Washington D.C.: USEPA, Office of Solid Waste. EPA 530/SW-1 10-OF

46. USEPA, 1996. Characterization of municipal solid waste in the United States: 1995 update. Washington D.C.: USEPA. EPA/530-R-945-001.

47. Van Tassel, A.J. (Ed.), 1973. Our environment: The outlook of 1980, Lexington, Mass.: Lexington Books.

48. Waters L., 1993. Waste not, want not, American City and County, Vol. 108, No. 7, June, 38, 42.

49. White, P.T., 1983. The fascinating world of trash, National Geographic, Vol. 30, No. 4, 45-50.

50. Williams M.E., 1994. Integrated municipal solid waste management. In Handbook of Solid Waste Management, ed. Kreith F., New York: Mc-Graw-Hill, Inc., 2.1-2.16.

51. Wilt C.A., Davis G.A., 1996. Local control wasting away: Will Congress level the solid waste playing field?, Policy Studies Journal, Vol. 24, No. 1, Spring, 123-134.

52. Wiseman C., 1991. Dumping: Less wasteful than recycling, Wall Street Journal, July 18, A10. 